\title{
Kinetic aspects of the interaction of blood clotting enzymes
}

Citation for published version (APA):

Hemker, H. C., Vermeer, C., \& Govers-Riemslag, J. (1977). Kinetic aspects of the interaction of blood clotting enzymes: VII. The relation between clotting time and prothrombin concentration. Thrombosis and Haemostasis, 37(1), 81-85. https://doi.org/10.1055/s-0038-1649204

Document status and date:

Published: 01/01/1977

DOI:

10.1055/s-0038-1649204

Document Version:

Publisher's PDF, also known as Version of record

\section{Please check the document version of this publication:}

- A submitted manuscript is the version of the article upon submission and before peer-review. There can be important differences between the submitted version and the official published version of record.

People interested in the research are advised to contact the author for the final version of the publication, or visit the DOI to the publisher's website.

- The final author version and the galley proof are versions of the publication after peer review.

- The final published version features the final layout of the paper including the volume, issue and page numbers.

Link to publication

\footnotetext{
General rights rights.

- You may freely distribute the URL identifying the publication in the public portal. please follow below link for the End User Agreement:

www.umlib.nl/taverne-license

Take down policy

If you believe that this document breaches copyright please contact us at:

repository@maastrichtuniversity.nl

providing details and we will investigate your claim.
}

Copyright and moral rights for the publications made accessible in the public portal are retained by the authors and/or other copyright owners and it is a condition of accessing publications that users recognise and abide by the legal requirements associated with these

- Users may download and print one copy of any publication from the public portal for the purpose of private study or research.

- You may not further distribute the material or use it for any profit-making activity or commercial gain

If the publication is distributed under the terms of Article $25 \mathrm{fa}$ of the Dutch Copyright Act, indicated by the "Taverne" license above, 


\section{THROMBOSIS \\ AND HAEMOSTASIS}

(formerly Thrombosis et Diathesis Haemorrhagica)

Journal of the International Society on Thrombosis and Haemostasis
No. 1 - Vol. 37

February 28, 1977

Editor:

Dr. Rosemary Biggs, Oxford

Associate Editors: C. R. Rizza, Oxford · F. Duckert, Basel - H. R. Roberts, Chapel Hill · P. N. Walsh, Philadelphia J. P. Caen, Paris · V. J. Marder, Philadelphia · E. A. Beck, Bern

\section{Kinetic Aspects of the Interaction of Blood Clotting Enzymes}

\section{The Relation between Clotting Time and Prothrombin Concentration}

H. C. Hemker, C. Vermeer, and J. Govers-Riemslag

From the Department of Biochemistry, Biomedical Centre,

State University Limburg, Maastricht, The Netherlands

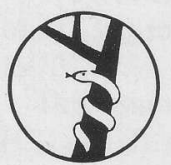




\title{
Kinetic Aspects of the Interaction of Blood Clotting Enzymes
}

\section{The Relation between Clotting Time and Prothrombin Concentration}

\author{
H. C. Hemker, C. Vermeer, and J. Govers-RiemslaG \\ From the Department of Biochemistry, Biomedical Centre, \\ State University Limburg, Maastricht, The Netherlands
}

\section{Summary}

The relation between clotting time and the inverse of prothrombin concentration is shown to be rectilinear.

\section{Introduction}

In previous articles (Hemker et al. 1965, Hemker et al. 1968) we developed a theory on the relation between the clotting time and the concentration of the coagulation factors of the extrinsic system.

We proposed that this relation is of the type

$\mathrm{t}_{\mathrm{c}}=\mathrm{a} \cdot 1 / \mathrm{c}+\mathrm{b}$

where $t_{c}$, the coagulation time obtained with a concentration $c$,

$\mathrm{c}$, the concentration of the rate limiting coagulation factor,

$a, b$, constants.

The relation holds true for situations where one factor is rate limiting (i. e. present in concentrations of $0-10 \%)$ and the other factors are present in relative excess $(>35 \%)$.

Until now we could not give direct experimental proof of the validity of formula (1) because of experimental limitations. For testing formula (1) one has to add known amounts of the rate limiting factor to a medium in which all other factors are present in excess. For example, small amounts of prothrombin to a prothrombin reagent. A prothrombin reagent until now always contained a small residual activity of prothrombin, equivalent to a small unknown concentration $(\mathrm{L})$, as shown by the observation that a finite clotting time (buffer time, $\mathrm{t}_{1}$ ) is obtained when no prothrombin is added to the sample. When one adds a concentration $\left(\mathrm{C}_{\text {added }}\right)$ the actual concentration acting in the reaction $\left(\mathrm{C}_{\text {total }}\right)=\left(\mathrm{C}_{\text {added }}+\mathrm{L}\right) \cdot \mathrm{C}_{\text {total }}$ is the independent variable of formula (1) and it is unknown because $\mathrm{L}$ is unknown.

We were not able to falsify the hypothesis that the following formula is valid: $\mathrm{t}_{\mathrm{c}}=\mathrm{a} .1 /\left(\mathrm{C}_{\mathrm{added}}+\mathrm{L}\right)+\mathrm{b}$

We worked out methods to determine $\mathrm{a}, \mathrm{L}$, and $\mathrm{b}$ from series of measurements of $\mathrm{t}_{\mathrm{c}}$ at various $\mathrm{C}_{\text {added }}$ including $\mathrm{C}_{\mathrm{added}}=0$, i. e. $\mathrm{t}_{\mathrm{c}}=\mathrm{t}_{\mathrm{e}}$ (buffer time) (Hemker et al. 1968, Hemker et al. 1972).

This amounts to making a three parameter fit to the experimental relationship $t_{c}=f$ $\left(\mathrm{C}_{\mathrm{added}}\right)$. It suffers from the drawback that it does not prove relationship (Hemker and 
Muller 1968) to have a physical meaning. It only shows formula (2) to be a simple valid mathematical description of $t_{c}=f\left(C_{a d d e d}\right)$ so that the assumptions on basis of which formula (2) was constructed cannot be refuted by experimental means.

These assumptions were

a) $t_{c}=a \cdot 1 / C_{\text {total }}+b$

b) $\mathrm{C}_{\text {total }}=\mathrm{C}_{\text {added }}+\mathrm{L}$

Because we recently found a method to prepare a factor II reagent devoid of any residual factor II (i. e. $\mathrm{L}=\mathrm{O}$ ) we are no longer dependent upon assumption $\mathrm{b}$ ) and we can test assumption a) directly, which is done in this paper.

\section{Materials and Methods}

Bovine factor II reagent was prepared by adding a preparation containing amongst others the factors VII and $\mathrm{X}$ to $\mathrm{BaSO}_{4}$ adsorbed bovine plasma containing $1 \mathrm{mM} \mathrm{Na}$ Oxalate, as described by Vermeer et al. 1976. The factor VII and X preparation was prepared from the serum obtained from normal bovine plasma upon coagulation with Echis Carinatus venom ( $1 \mathrm{mg} /$ litre), $50 \mathrm{ml}$ DEAE Sephadex A 50 slurry (in $0.06 \mathrm{M}$ Tris-citrate buffer $\mathrm{pH} 7.1$ was stirred in 3 litres of serum during 1 hour. The Sephadex was then packed into a column, washed with 1 litre of $0.15 \mathrm{M} \mathrm{NaCl}$ in $5 \mathrm{mM}$ Tris $\mathrm{HCl} \mathrm{pH} \mathrm{7.0.} \mathrm{Then} \mathrm{the} \mathrm{column} \mathrm{was}$ eluted with $1.0 \mathrm{M} \mathrm{NaCl}$ in $5 \mathrm{mM}$ Tris- $\mathrm{HCl} \mathrm{pH} \mathrm{7.0.} \mathrm{This} \mathrm{yields} \mathrm{factor} \mathrm{X}$ in a $55 \%$ recovery and factor VII in a $\sim 100 \%$ recovery in the peak fraction.

It contains the following concentrations of coagulation factors: factor I: $278 \mathrm{mg} \%$, factor II: $0 \%$, factor V: $47 \%$, factor VII $47.1 \%$, factor X: $41.0 \%$.

Factor II was prepared according to Owen et al. (1974). The preparation used was $>98 \%$ pure and devoid of demonstrable other coagulation activities. The coagulation tests and the preparation of normal pool plasma were carried out as described (Hemker et al. 1972). The three parameter fit of formula (2) to a series of $t_{c}, C_{\text {added }}$ data pairs was carried out with the computer program described in (Hemker et al. 1972), as well as by the analytical method by hand as described (Hemker et al. 1968). Both methods directly yield $a, L$, and $b$. The constant $b$ is given as $t_{\min }$, i. e. the coagulation time of the system at infinite concentration of the rate limiting coagulation factor $\left(\mathrm{C}_{\text {added }} \rightarrow \infty\right)$. The other constant given is not a, but $\mathrm{K}_{\mathrm{m}}=\mathrm{b} / \mathrm{a}$, which has the dimension of a concentration and the physical meaning of being that concentration at which half maximal reaction velocity is obtained.

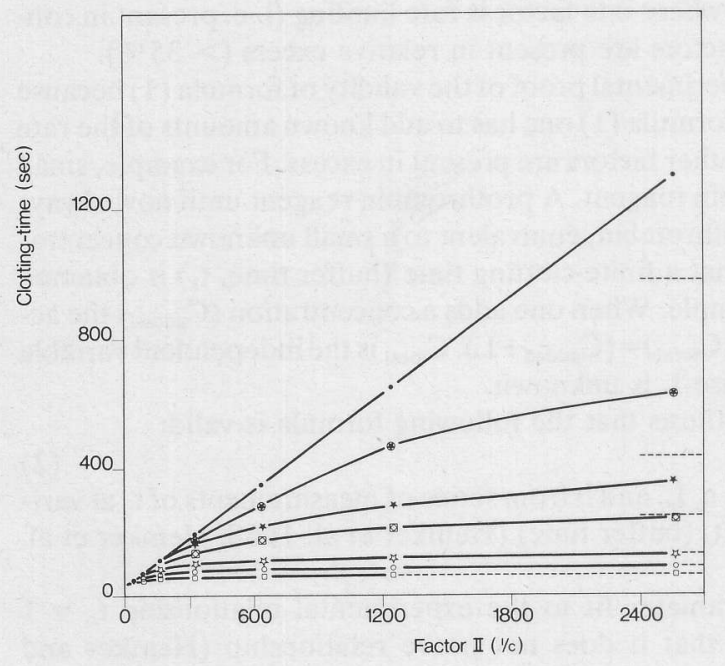

Fig. 1 Reference curves from prothrombin reagents with known added amounts of prothrombin.

$\square$ reagent $+2 \%$ factor II

0 reagent $+1 \%$ factor II

2 reagent $+0.5 \%$ factor II

reagent $+0.2 \%$ factor II

* reagent $+0.1 \%$ factor II

reagent $+0.05 \%$ factor II

- reagent $+0 \%$ factor II 


\section{Experiments}

With the aid of bovine normal plasma we investigated the $t_{c}-C_{a d d e d}$ relationship with the reagent devoid of factor II (Fig. 1, upper curve). It appears that the relation between $t_{c}$ and $1 / \mathrm{c}$ is rectilinear. Table 1 shows a statistical test on the rectilinearity of this relationship. It appears

Table 1 Test of the linearity of the function $\mathrm{t}=\mathrm{f}(1 / \mathrm{c})$.

\begin{tabular}{rrrrrr}
\hline $\mathrm{C}$ & $1 / \mathrm{c}$ & $\mathrm{t}(\mathrm{sec})$ & $\mathrm{s}(\mathrm{sec})$ & $\mathrm{s}(\%)$ & $\mathrm{t}_{\text {calc }}$ \\
\hline 10.00 & 10 & 37.3 & 1.1 & 3.0 & 38.5 \\
4.00 & 25 & 54.4 & 2.7 & 5.0 & 49.8 \\
1.00 & 100 & 103.3 & 2.9 & 2.8 & 106.1 \\
0.40 & 250 & 218.1 & 6.2 & 2.8 & 218.8 \\
0.10 & 1000 & 782.0 & 15.3 & 2.0 & 782.2 \\
\hline
\end{tabular}

$\mathrm{C}$ is the prothrombin concentration in $0.01 \mathrm{U} / \mathrm{ml}$. $\mathrm{t}$ is the mean clotting time from 20 determinations. $\mathrm{s}$ is the standard deviation. $t_{\text {calc }}$ is the calculated clotting time from the regression line through the experimental points $(t=0.7512 \times 1 / \mathrm{c}+31.0)$. The hypothesis that the line is not straight can be rejected below the $\alpha=0.01$ level.

Table 2 Values of $\mathrm{L}, \mathrm{t}_{\min }$ and $\mathrm{K}_{\mathrm{m}}$ calculated for prothrombin reagents with known added amounts of prothrombin.

\begin{tabular}{lllllll}
\hline $\mathrm{C}(\%)$ & $\mathrm{L}_{1}(\%)$ & $\mathrm{L}_{2}(\%)$ & $\mathrm{t}_{\min }(\mathrm{sec})$ & $\mathrm{K}_{\mathrm{m}}(\%)$ & $\mathrm{t}_{1}(\mathrm{sec})$ & s. d. $(\%)$ \\
\hline 2 & 1.84 & 2.00 & 28.2 & 2.32 & 62 & 2.00 \\
1 & 1.98 & 1.40 & 28.8 & 2.23 & 88 & 1.40 \\
0.2 & 0.29 & 0.18 & 31.3 & 2.23 & 237 & 0.18 \\
0.1 & 0.15 & 0.14 & 33.3 & 1.89 & 426 & 0.14 \\
0.05 & 0.045 & 0.05 & 34.5 & 1.93 & 979 & 0.05 \\
0 & 0 & 0 & 28.8 & 2.24 & $\sim$ & 0
\end{tabular}

C: amount of prothrombin added to the reagent. $\mathrm{L}_{1}: \mathrm{C}$ as from the $\mathrm{t}_{\mathrm{c}}-\mathrm{C}_{\text {added }}$ data pairs by the method of ref. 3. $L_{2}$ : as $L_{1}$, but calculated by hand with the method of ref. 1 . $t_{1}$ : clotting time at $C_{\text {added }}=0$ (buffer time). $t_{\min }, K_{m}$ : see text. s. d.: standard error of the mean of four determinations at each concentration from the relationship computed (Hemker et al. 1972).

Fig. 2 Reference curves from prothrombin reagents with known added amounts of prothrombin. Log-log plot. For further details see the legend to Fig. 1.

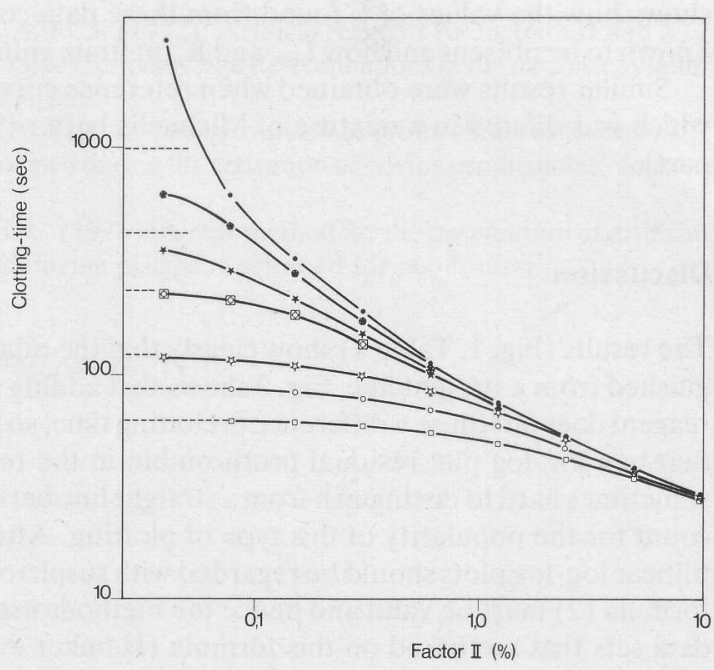




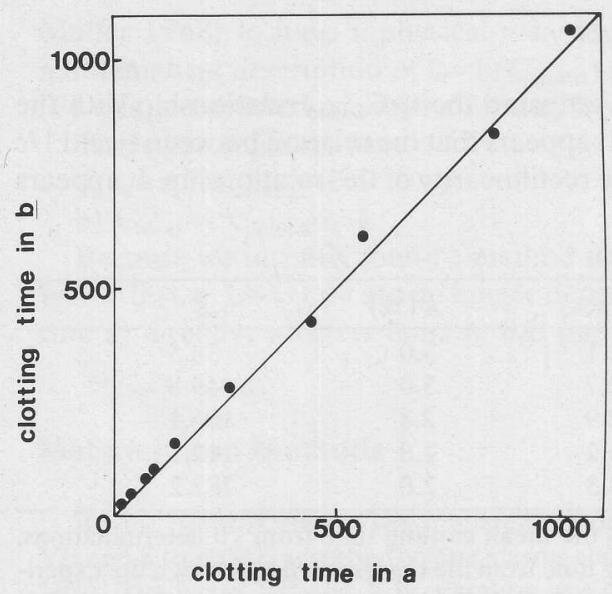

Fig. 3 Influence of the order of addition of prothrombin to the reaction mixture. Experiment a: 9 volumes of prothrombin reagent were supplied with one volume of purified prothrombin in Michaelis buffer in varying dilutions. The mixture was left for 1 hour. Then the clotting time was recorded of $0.1 \mathrm{ml}$ of this mixture with $0.1 \mathrm{ml}$ thromboplastin, $0.1 \mathrm{ml} \mathrm{BaSO}_{4}$ adsorbed plasma and $0.1 \mathrm{ml}$ of $\mathrm{CaCl}_{2} 33 \mathrm{mM}$. Experiment b: 9 volumes of $\mathrm{BaSO}_{4}$ adsorbed plasma were supplied with one volume of purified prothrombin to obtain the same range of concentrations as in experiment a. Mean of three determinations.

impossible to prove that the relationship is not rectilinear. On the other hand the log-log plot obviously is curved (Fig. 2, upper curve).

Next we added small amounts of purified prothrombin or plasma to the reagent and assessed that this change in order of addition of prothrombin to the final reaction mixture did not alter the eventual clotting time (Fig. 3).

It was, therefore, concluded that prothrombin in the reagent behaves similar to prothrombin in the sample so that formula (2) indeed can be used. Then we added small amounts of prothrombin to the reagent and made reference curves with dilutions of normal plasma (Figs. 1 and 2 ). The parameters $t_{\min }, K_{m}$ and $L$ in Table 1 were those fitted to these data sets. This table also shows how the values of $\mathrm{L}$ found from these data compared to the amounts of prothrombin known to be present and how $\mathrm{t}_{\min }$ and $\mathrm{K}_{\mathrm{m}}$ at finite values of $\mathrm{L}$ compared to those found at $\mathrm{L}=0$.

Similar results were obtained when reference curves were prepared from purified factor II which was diluted in a mixture of Michaelis buffer ( 9 parts) and $\mathrm{BaSO}_{4}$ adsorbed plasma (1 part).

\section{Discussion}

The results (Fig. 1, Table 1) show clearly that the relation between $t_{c}$ and $1 / c$ cannot be distinguished from a straight line. Fig. 3 shows that adding prothrombin with the sample or with the reagent does not cause a difference in clotting time, so that formula (4) seems valid. Fig. 2 shows that in a $\log -\log$ plot residual prothrombin in the reagent causes sigmoid curves, which are sometimes hard to distinguish from a straight line between 1.0 and $10 \%$ factor II. This may account for the popularity of this type of plotting. Attempts to find a theoretical basis for rectilinear log-log plots should be regarded with suspicion. When both formulas 3 and 4 are valid, formula (2) must be valid and hence the methods used to assess $L, t_{\min }$ and $K_{m}$ from $t_{c}-C_{\text {added }}$ data sets that are based on this formula (Hemker et al. 1965, 1968) must be valid. Table 1 
shows that the three parameter fit of formula (2) of the experimental $t_{c}-C_{\text {added }}$ data sets gave values of $\mathrm{L}$ that were indeed in fair agreement to the amounts of prothrombin added. This justifies the use of this method in determining the residual prothrombin activity in deficient plasma's: one simply uses the deficient plasma as a reagent, determines the reference curve and from this calculates the value of $\mathrm{L}$. From Table 2 it is also seen that those parameters that represent chemical constants of the system $\left(t_{\min }\right.$ and $\left.\mathrm{K}_{\mathrm{m}}\right)$ are indeed virtually independent of the amount of prothrombin added.

We conclude that the two basic assumptions which we used to explain the observed fit of formula (2) to the experimental data are independently proven to be valid, i. e.

1. the relation between clotting time and prothrombin concentration is as described by formula (1);

2. this relation is usually obscured by residual prothrombin activity in the reagent.

\section{Résumé}

On montre que la relation entre le temps de coagulation et l'inverse de la concentration de la prothrombine est rectiligne.

\section{Zusammenfassung}

Es wird gezeigt, daß sich Gerinnungszeit und die reziproke Prothrombinkonzentration rektilinear verhalten.

\section{References}

Hemker, H. C., Hemker, P. W. and Loeliger, E. A. (1965): Kinetic aspects of the interaction of blood clotting enzymes. I. Derivation of basic formulas. Thrombosis et Diathesis Haemorrhagica 13, 155.

HemKer, H. C. and Muller, A. D. (1968): Kinetic aspects of the interaction of blood clotting enzymes. V. One-stage estimations in the extrinsic coagulation system. Thrombosis et Diathesis Haemorrhagica 19, 368.

Hemker, H. C., Swart, A. C. W. and Alink, A. M. J. (1972): Artifical reagents for factor VII and X, a computer program for obtaining reference tables for one-stage determinations in the extrinsic system. Thrombosis et Diathesis Haemorrhagica 27, 205.

Owen, W. G., EsMON, C. T. and JACKson, W. M. (1974): The conversion of prothrombin to thrombin. I. Characterization of the reaction products formed during the activation of bovine prothrombin. Journal of Biological Chemistry 249, 594.

Vermeer, C., Soute, B. A. M. and Hemker, H. C. (1976): A new method for the preparation of artificial factor II reagents from normal human and bovine plasma. Submitted for publication.

Received 12th February, 1976 Accepted 20th August, 1976 